\title{
Molecular Characterization of Conditionally Immortalized Cell Lines Derived From Mouse Early Embryonic Inner Ear
}

John A. Germiller, ${ }^{1,2 \dagger \ddagger}$ Elizabeth C. Smiley, ${ }^{1 \dagger}$ Amanda D. Ellis, ${ }^{1}$ Jessica S. Hoff, ${ }^{1}$ Ian Deshmukh, ${ }^{1}$ Susan J. Allen, ${ }^{1}$ and Kate F. Barald ${ }^{1 *}$

Inner ear sensory hair cells (HCs), supporting cells (SCs), and sensory neurons (SNs) are hypothesized to develop from common progenitors in the early embryonic otocyst. Because little is known about the molecular signals that control this lineage specification, we derived a model system of early otic development: conditionally immortalized otocyst (IMO) cell lines from the embryonic day 9.5 Immortomouse. This age is the earliest stage at which the otocyst can easily be separated from surrounding mesenchymal, nervous system, and epithelial cells. At 9.5 days post coitum, there are still pluripotent cells in the otocyst, allowing for the eventual identification of both SN and HC precursors - and possibly an elusive inner ear stem cell. Cell lines derived from primitive precursor cells can also be used as blank canvases for transfections of genes that can affect lineage decisions as the cells differentiate. It is important, therefore, to characterize the "baseline state" of these cell lines in as much detail as possible. We characterized seven representative "precursor-like" IMO cell populations and the uncloned IMO cells, before cell sorting, at the molecular level by polymerase chain reaction (PCR) and immunocytochemistry (IHC), and one line (IMO-2B1) in detail by real-time quantitative PCR and IHC. Many of the phenotypic markers characteristic of differentiated HCs or SCs were detected in IMO-2B1 proliferating cells, as well as during differentiation for up to $\mathbf{3 0}$ days in culture. These IMO cell lines represent a unique model system for studying early stages of inner ear development and determining the consequences of affecting key molecular events in their differentiation. Developmental Dynamics 231:815-827, 2004. ๑ 2004 Wiley-Liss, Inc.

Key words: gene expression; hair cells; supporting cells; cell line models; auditory system development

Received 31 March 2004; Revised 21 July 2004; Accepted 21 July 2004

\section{INTRODUCTION}

\section{Early Stages of Otic Development}

The development of the vertebrate inner ear is a complex, highly orchestrated process. The mouse and chick epithelial otic placodes invaginate to form the otocyst (otic vesicle), which appears to be a simple epithelial sac. This structure will eventually give rise to the complex membranous labyrinth with its enclosed sensory organs. However, even from early times, day 9 post coitum in the mouse, the Hamburger and Hamilton $(\mathrm{HH}$ ) stage 12 (Hamburger and Hamilton, 1951) otic vesicle in the chick and the prim5 (24 hr) stage in the cavitating (rather than invagi- nating) zebrafish otocyst, the vertebrate otocyst contains cells that are committed to specific inner ear cell fates (reviewed in Barald and Kelley, 2004). At these early stages, the unique environment surrounding the otocyst influences its development. Signals from the hindbrain, the undifferentiated mesenchyme surrounding the otocyst (periotic mesen-

\footnotetext{
${ }^{1}$ Department of Cell and Developmental Biology, Program in Cell and Molecular Biology, Program in Neuroscience, University of Michigan, Ann Arbor, Michigan

${ }^{2}$ Department of Otolaryngology-Head and Neck Surgery, University of Michigan, Ann Arbor, Michigan

Grant sponsor: the NIH; Grant number: RO1DC04184; Grant number: R01 DC05939; Grant sponsor: NSF; Grant number: IBN9906424; Grant sponsor: the Deafness Research Foundation; Grant sponsor: the American Academy of Otolaryngology-HNS.

†.A. Germiller and E.C. Smiley contributed equally to this work

‡Dr. Germiller's present address is Division of Otolaryngology, Children's Hospital of Philadelphia, Philadelphia, PA.

*Correspondence to: Kate F. Barald, Department of Cell and Developmental Biology, University of Michigan, 1150 W. Medical Center Drive, Ann Arbor, MI 48109-0616. E-mail: kfbarald@umich.edu

DOI 10.1002/dvdy.20186

Published online 29 October 2004 in Wiley InterScience (www.interscience.wiley.com).
} 
chyme/POM), the notochord, and the neural crest (NC) provide inductive and patterning information necessary for normal inner ear development (Fritzsch et al., 1997; Fritzsch and Beisel, 2001; Fekete and Wu, 2002; Liu et al., 2003b; Barald and Kelley, 2004). By day 2 of chick embryonic development (embryonic day (E) 2; HH stage 13), genes important for otic development are regionalized, with well-defined borders. Parallels to this organization also exist in mouse, zebrafish, and Xenopus (Fekete, 1996, 2000a,b; Brigande et al., 2000a; Lang et al., 2000; Fekete and Wu, 2002; Barald and Kelley, 2004).

\section{Cell Specification and Differentiation}

Cells in the epithelium of the otic vesicle give rise to specialized sensory structures, among other cell types. Hair cells (HCs) develop within the cochlear duct and in other inner ear sensory organs, including vestibular organs. Primary sensory neurons (SNs) of the statoacoustic ganglion (SAG), which later contribute to cranial nerve VIII, delaminate as precursors from the otic crest (Hemond and Morest, 1991). It is still unclear whether HCs, supporting cells (SCs), and SNs are derived from a common precursor cell (Fritzsch and Beisel, 2001; Barald and Kelley, 2004). Viral tracing studies did not find any progeny of labeled cells that gave rise to both a $\mathrm{HC}$ and a SN, but the authors (Lang and Fekete, 2001) also could not rule out this possibility in their experiments.

Sensory epithelia are intricately patterned so that each $\mathrm{HC}$ is separated from other HCs by intervening SCs that form an invariant and alternating mosaic throughout sensory organs, including the cochlear duct (Echteler et al., 1994; Barald and Kelley, 2004). This alternating pattern is postulated to result from the process of lateral inhibition (Adam et al., 1998; Lanford et al., 1999), in which some cells within a collective assume a certain fate, and then inhibit their neighbors from doing the same (Lewis, 1996; Kimble and Simpson, 1997; Kopan and Cagan, 1997; Lanford et al., 1999). Recent work has implicated the Notch signaling paradigm in molecular control of this process. In the developing cochlea, Notch-1 and its ligand jagged-2 are expressed in alternating cell types, starting at E14.5 in the basal turn (Lanford et al., 1999), with jagged-2 restricted to presumptive HCs.

\section{Markers of $\mathrm{HC}$ and SC}

During later developmental stages, the expression of several genes becomes restricted to sensory organs, and then specifically to HCs and/or SCs; these genes have been used as cell phenotype markers in the inner ear. One of the earliest-expressed genes specifically in HCs is murine atonal homolog-1 (Math-1), a basic helix-loop-helix transcription factor, which first appears in the sensory epithelium of the utricle, saccule, semicircular canals, and cochlea, and becomes restricted to $\mathrm{HCs}$ by the end of gestation (Bermingham et al., 1999; Kawamoto et al., 2003). Another early "HC-specific" gene product is Brn3.1 (POU4F3, Brn3C), a POU family transcription factor essential for $\mathrm{HC}$ differentiation and survival (Erkman et al., 1996; Ryan, 1997; Xiang et al., 1997). Mutations in Brn3.1 (DFNA15) were shown to cause familial adult onset progressive hearing loss in humans (Vahava et al., 1998). Later, HCs express unique $\alpha 9$ and $\alpha 10$ subunits of the nicotinic acetylcholine receptor ( $\alpha 9$ and $\alpha 10$ AChRs; Elgoyhen et al., 1994, 2001; Glowatski et al., 1995). Several other genes are expressed exclusively by HCs, including myosin VIIA (Hasson et al., 1997), parvallbumin 3 (PV3, Heller et al., 2002), and the Notch ligand jagged-2. Several genes have been identified that are characteristic of SCs and absent from HCs. These genes include the cytokeratins, which are nonspecific epithelial markers; the $\alpha$ - and $\beta$-tectorins (Legan et al., 1997); jagged-1; and the transcription factors HES- 1 and HES-5. The last three genes mediate Notch signaling in presumptive SCs in early cochlear patterning (Weir et al., 2000). Zic genes have been postulated to affect the fate of precursor cells common to neurons or sensory HCs by affecting expression of downstream atonal class genes, which may themselves be regulated by bone morpho- genetic proteins (BMPs) and their antagonists (Warner et al., 2003; Barald and Kelley, 2004).

\section{BMP Signaling System}

We are beginning to learn more about the molecular factors that regulate inner ear development (reviewed in Barald and Kelley, 2004). Recent evidence points to the BMP4 signaling system as being of critical importance for inner ear development (Hogan et al., 1994; Wall and Hogan, 1994). In the developing ear, BMP4 is one of the earliest genes and is expressed as early as the otic placode stage. It then becomes localized to distinct regions of the developing otocyst (Hemmati-Brivanlou and Thomsen, 1995; Oh et al., 1996; Morsli et al., 1998; Gerlach et al., 2000; Cole et al., 2000) and later to specific regions of the inner ear destined to produce sensory tissue (Morsli et al., 1998; Barald and Kelley, 2004).

BMP4 signaling during development is modulated by the action of several endogenous antagonists that block BMP4 downstream signaling. Three of these, noggin, DAN, and chordin, play a critical modulatory role in BMP signaling during development of many organ systems (reviewed in Thomsen, 1997 and Barald and Kelley, 2004). Noggin is expressed in the POM in the early stage chick embryo (Gerlach et al., 2000). Furthermore, antagonism of BMP4 by exogenously applied antagonists results in profound, specific malformations of the inner ear, particularly of the semicircular canals (SCC; Chang et al., 1999; Gerlach et al., 2000). DAN is expressed in the early developing chick medial otic epithelium and in the mouse POM (Gerlach-Bank et al., 2002). Both gain- and loss-of-function experiments show that DAN has a role in ED/ES development and may help partition the epithelium into the $\mathrm{ED} / \mathrm{ES}$ and the anterior and posterior SCC (Gerlach-Bank et al., 2004).

\section{Immortalized Otocyst Cell Lines as Models of Early Otic Development}

Historically, molecular studies of the developing and mature inner ear 
have been hampered by difficult access to the temporal bone, the small size of the developing sensory organs, and in particular the absence of good organ and cell culture models of the early inner ear. Therefore, our laboratory (Barald et al., 1997) and other researchers (Holley et al., 1997; Kalinec et al., 1999) developed conditionally immortalized cell lines from the mouse inner ear. Our cell lines were derived from the earliest stage that otocysts could be excised from 9- to 9.5-day embryos. We used the H2K ${ }^{\mathrm{b}} \mathrm{tsA} 58$ transgenic mouse (Immortomouse), which carries a temperature-sensitive variant of the SV40 large T antigen under the control of a $\gamma$-interferon-sensitive promoter (Jat et al., 1991; reviewed in Noble, 1999). Immortomouse otocyst (conditionally immortalized otocyst, IMO) cells proliferate in the presence of $\gamma$-interferon at $32-33^{\circ} \mathrm{C}$, the permissive temperature for transgene expression, but stop proliferating and differentiate after temperature shift to $37^{\circ}-39^{\circ} \mathrm{C}$ and withdrawal of $\gamma$-interferon. Because the native otocyst harbors progenitors of nearly all cells in the inner ear, our hypothesis is that immortalized cells should, given the right culture conditions, eventually demonstrate characteristics of multiple divergent sensory and nonsensory phenotypes as they differentiate. Initially, they would have characteristics of "common precursor" or multipotent cells. By varying the culture conditions, including cell-cell interactions and/or transfecting genes hypothesized to predispose these cells into specific lineages, we can use this model to determine which genes are important for the development of identified cell types.

A major aim of auditory system research is to discover the fundamental differences that allow chicks to regenerate a sensory epithelium, whereas mammals cannot (Stone and Rubel, 2000a,b). One notable difference between chicks and mice is that mature $\mathrm{HCs}$ of chicks express BMP4, although SCs do not. The reverse is true in the mature mouse ear, where SCs but not HCs express BMP4. We hypothesize that, in both the chick and the mouse, the common precursor cell (Brigande et al., 2000b) expresses BMP4 (Barald and Kelley, 2004). We therefore targeted mouse IMO cells that express BMP4 for initial characterization, because they are excellent candidates for common precursor cells and perhaps precursors to SN as well. We analyzed the expression of a panel of markers associated with developing and mature $\mathrm{HC}, \mathrm{SC}$, and nonsensory inner ear epithelia in selected BMP4-expressing IMO cell lines and in the uncloned, unsorted Immortomouse otocyst (UIMO), isolated from the original E9.5 mouse otocysts. The clonal cell lines were derived by fluorescence-activated cell sorting (FACS)/light scattering cloning (Barald et al., 1997).

We also tested the hypothesis that spatially restricted cues such as cellcell interactions in culture influence phenotype development on a local level, as is true in the living ear (Barald and Kelley, 2004). We have studied expression of genes associated with BMP4 and Notch signaling, including BMP4 and related growth factors, BMP receptors, three BMP antagonists (noggin, chordin, and DAN), Notch-1, and its ligand jagged-2. We have also examined the expression of Zic genes, which we hypothesize are downstream effectors of BMP4/chordin antagonistic cascades and potentially important for neuronal or $\mathrm{HC}$ specification (Warner et al., 2003; Barald and Kelley, 2004). One of the cell lines, IMO-2B1, which we hypothesize is a good model for an early "precursor cell," has been characterized in detail in this study by real-time quantitative polymerase chain reaction (PCR) with a panel of 50 primer pairs characteristic of HCs, SCs, SNs, and presumptive precursor cells. We wish to describe in as much detail as possible the baseline state of these cells before determining effects of specific gene transfections, cell-cell interactions, or culture conditions. We have already successfully used this cell line to identify a novel BMP4 promoter in intron 2, which our subsequent studies demonstrated is also expressed in the inner ears of both chicks and mice (Thompson et al., 2003).

\section{RESULTS AND DISCUSSION Gene Expression Profiling by PCR}

A PCR analysis was used to measure expression for a panel of genes important in inner ear development. These fell into four categories: (1) genes involved in BMP signaling; (2) other signaling genes, including those involved in Notch signaling; (3) markers for the differentiated HCs; and (4) SC phenotypes. Equal quantities of RNA were used for all genes tested to provide a sense of relative abundance of the various mRNAs. The E15 mouse embryo was used as a control for primer efficiency, not staging of the inner ear. Seven different BMP4-expressing cell lines and the UIMO cells were screened for gene expression by conventional PCR at 0 (proliferative) and 15 days of differentiation; IMO-2B1 cells were tested more frequently $(0,3,7,15$, and 30 days of differentiating conditions; Table 1; Fig. 1).

In all of the IMO cell lines tested (Table 1), BMP4 and its receptors were detected at very high levels during proliferation and levels were unchanged after differentiation. Chordin and noggin were detected in many of the cell lines, but expression levels were variable. BMP signaling genes included secreted growth factors of the BMP/transforming growth factor- $\beta$ superfamily (BMPs 2 , 4 , and 6 , and activins $\beta A$ and $\beta B$ ), the type 1A and type 2 BMP4 receptors, and three secreted antagonists of BMP4: noggin, chordin, and DAN (Gerlach-Bank et al., 2004).

An expression profile was first established over time in UIMO cells, which represent a random cell sample of the otocyst as a whole. A representative cell line, IMO-2BI (Fig. 1) is one of the cell lines cloned from the UIMO by light scattering on a FACS (Barald et al., 1997). High levels of expression of BMP4, the activins, and the BMP4 receptor mRNAs were found in both UIMO and IMO-2BI cells, with expression remaining high throughout differentiation (Fig. 1). The same pattern was found for chordin and DAN; noggin was found in UIMO cells after differentiation and in both proliferating and differ- 
TABLE 1. Gene Expression Profiling of Clonal IMO Cell Lines Selected on the Basis of their BMP4 Expression, Grown under Proliferative ( $P$ ) and Differentiating $(D)$ Culture Conditions in Comparison to the Expression in the Early Mouse Whole Embryo (E15)

\begin{tabular}{|c|c|c|c|c|c|c|c|c|c|c|c|c|c|c|c|}
\hline \multirow[b]{2}{*}{ Gene } & \multirow[b]{2}{*}{ Embryo $^{a}$} & \multicolumn{2}{|c|}{$1 G 1$} & \multicolumn{2}{|c|}{$2 \mathrm{~B} 1$} & \multicolumn{2}{|c|}{ 2D2 } & \multicolumn{2}{|c|}{ 2D3 } & \multicolumn{2}{|c|}{$3 \mathrm{~A} 1$} & \multicolumn{2}{|c|}{$3 C 3$} & \multicolumn{2}{|c|}{ 3D 1} \\
\hline & & $P$ & $\bar{D}$ & $\mathrm{P}$ & $\bar{D}$ & $\mathrm{P}$ & $\bar{D}$ & $P$ & $\bar{D}$ & $P$ & $\bar{D}$ & $P$ & $\bar{D}$ & $P$ & $D$ \\
\hline BMP4 & 4 & 4 & 4 & 4 & 4 & 4 & 4 & 4 & 4 & 4 & 4 & 4 & 4 & 4 & 4 \\
\hline BMP4 R1A & 4 & 4 & 4 & 4 & 4 & 4 & 4 & 4 & 4 & 4 & 4 & 4 & 4 & 4 & 3 \\
\hline BMP4 R2 & 3 & 3 & 3 & 3 & 3 & 3 & 3 & 3 & 3 & 3 & 3 & 3 & 3 & 2 & 2 \\
\hline chordin & 4 & 4 & 4 & 4 & 4 & 4 & 4 & 3 & 2 & 2 & 4 & 4 & 4 & 0 & 0 \\
\hline noggin & 3 & 2 & 4 & 4 & 4 & 4 & 4 & 0 & 1 & 3 & 3 & 1 & 2 & 0 & 0 \\
\hline jagged 1 & 4 & 4 & 4 & 4 & 4 & 4 & 4 & 4 & 4 & 4 & 4 & 4 & 4 & 3 & 4 \\
\hline jagged 2 & 4 & 3 & 3 & 3 & 3 & 3 & 3 & 3 & 3 & 2 & 3 & 3 & 3 & 2 & 2 \\
\hline notch 1 & 4 & 4 & 4 & 4 & 4 & 4 & 4 & 4 & 4 & 4 & 4 & 4 & 4 & 4 & 4 \\
\hline Math 1 & 3 & 2 & 1 & 0 & 0 & 0 & 3 & 0 & 2 & 2 & 0 & 0 & 1 & 0 & 0 \\
\hline$\alpha-9$ AChR & 3 & 1 & 0 & 1 & 0 & 0 & 0 & 0 & 0 & 0 & 0 & 0 & 1 & 0 & 0 \\
\hline$\alpha-10$ AChR & 1 & 1 & 1 & 1 & 1 & 2 & 1 & 0 & 0 & 2 & 1 & 1 & 1 & 0 & 0 \\
\hline brn 3.1 & 3 & 3 & 2 & 2 & 1 & 2 & 1 & 0 & 2 & 2 & 0 & 3 & 3 & 1 & 1 \\
\hline myosin $7 a$ & 3 & 4 & 2 & 4 & 4 & 4 & 4 & 4 & 4 & 4 & 4 & 4 & 4 & 4 & 4 \\
\hline HES 1 & 3 & 3 & 3 & 3 & 3 & 3 & 3 & 3 & 3 & 3 & 3 & 3 & 3 & 3 & 3 \\
\hline HES 1 & 3 & 1 & 0 & 0 & 0 & 0 & 0 & 0 & 0 & 0 & 0 & 0 & 0 & 0 & 0 \\
\hline$\alpha$-tectorin & 2 & 3 & 3 & 2 & 2 & 2 & 2 & 2 & 3 & 2 & 2 & 3 & 2 & 2 & 2 \\
\hline$\beta$-tectorin & 3 & 0 & 0 & 0 & 0 & 0 & 0 & 0 & 0 & 0 & 0 & 0 & 1 & 0 & 0 \\
\hline pendrin & 1 & 1 & 0 & 1 & 0 & 1 & 0 & 0 & 0 & 0 & 0 & 2 & 2 & 1 & 1 \\
\hline Zic 1 & $3^{b}$ & 2 & 4 & 0 & 0 & 0 & 0 & 0 & 2 & 1 & 1 & 2 & 0 & 0 & 2 \\
\hline Zic 2 & 3 & 1 & 0 & 4 & 4 & 0 & 3 & 1 & 2 & 2 & 3 & 2 & 2 & 0 & 0 \\
\hline GAPDH & 4 & 4 & 4 & 4 & 4 & 4 & 4 & 4 & 4 & 4 & 4 & 4 & 4 & 4 & 4 \\
\hline
\end{tabular}

aMouse embryo RNA, embryonic day 15; Scoring: 0, negative; 1, barely visible; 2 , visible; 3 , strong; 4 , very heavy expression. E, embryonic day.

entiated IMO-2BI cells in most experiments (Table 1), although levels are low in the experiment illustrated in Figure 1. However, noggin was not found in mouse inner ear RNA, the kind gift of Drs. Margaret Lomax (E15) and David Kohrman (postnatal, $\mathrm{P}=1$; Fig. 1). BMP6 was detected in both cell groups under all conditions but at lower levels overall than BMP4. BMP2 was strongly expressed in UIMO under proliferative conditions and after 15 days of differentiation. In IMO-2B1, BMP2 expression became undetectable after 3 days of differentiation (Fig. 1), and it was not found at all by real-time quantitative PCR (rt-qPCR; Fig. 2).

\section{Expression of Phenotypic Markers of Auditory Hair Cells}

In both UIMO cells and clonal IMO2B1 (Figs. 1, 2; Table 1), RNAs for multiple markers of the $\mathrm{HC}$ phenotype were detected in proliferating cells as well as long-term differentiated cultures. For both cell populations, myosin VIla was most abundant and was expressed at relatively constant levels throughout differentiation. Similarly, jagged-2, a participant in Notch signaling and an early marker of the HC phenotype, was detected at very high levels in both UIMO and IMO-2BI and the other IMO cell lines at all stages (Table 1). The other four $\mathrm{HC}$-associated genes, Brn-3.1, the $\alpha 9$ and $\alpha 10$ AChRs, and Math-1, were detected at much lower levels and with variable temporal patterns. The $\alpha 10$ receptor was found at low levels in approximately half of the cell lines; $\alpha 9$ was barely detectable in only three of the cell lines (Table 1). In UIMO cells, Brn-3.1, the $\alpha 9$ and $\alpha 10$ were detectable during both growth and differentiation (Fig. 1). In cell line IMO-2B1, Brn3.1, $\alpha$ 9, and $\alpha 10$ were detectable both in proliferating and differentiated cells in the qualitative PCR experiment, but expression levels appeared to drop significantly early in differentiation, then recover by the end of the 30day differentiation period. Brn3.1/ POU4F3 was found in many cell lines but with considerable variation, a finding that may allow interesting comparisons if the cells are used to study the role of this transcription factor in ear development. Brn3.1 expression was highest in IMO3C3 and IMOIGI.

Math-1 was not detected in IMO2B1 and was only barely detectable in UIMO cells (Fig. 1). Math-1 is critical for specification of the $\mathrm{HC}$ fate in vivo (Bermingham et al., 1999; Kawamoto et al., 2003), and we had predicted its presence in IMO cells before or concomitant with $\mathrm{HC}$ gene expression. Apparently, expression of Math-1 is either not essential for expression of certain $\mathrm{HC}$ genes, including myosin VIla and Brn3. 1, or is down-regulated early, at least in these cell lines. An identical situation was found in conditionally immortalized cells from the organ of Corti (UB/OC-1, Rivolta et al., 2002), which express numerous $\mathrm{HC}$ genes in the absence of Math-1. All HC phenotype markers were easily detected in the inner ear and in whole embryo tissues. 


\begin{tabular}{|c|c|c|c|c|}
\hline & UIMO & Clonal Cell L & ine IMO-2B1 & Controls \\
\hline & $\begin{array}{l}(-) R T \\
* \quad *\end{array}$ & Dave Diff & $(-) R T$ & 买 \\
\hline & $Q^{\circ} \leqslant 0^{\circ}<^{\circ} र^{\circ}$ & Q & 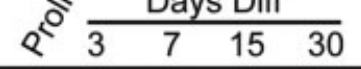 & $\dot{\psi}^{2}$ \\
\hline BMP-2 & 3 & $\theta$ & & $6=$ \\
\hline BMP-4 & 0 & $\theta$ & & 050 \\
\hline BMP-6 & -0 & $-0--0$ & & $06-$ \\
\hline Activin $\beta-A$ & 00 & 10 & & $\theta$ \\
\hline Activin $\beta-B$ & $-\infty$ & 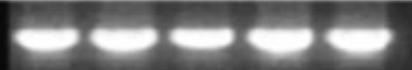 & & --2 \\
\hline BMPR 1a & 3 & J & & 000 \\
\hline BMPR 2 & 00 & & & 50 \\
\hline noggin & - & & & 0 \\
\hline chordin & $=0$ & & & 0 \\
\hline DAN & 00 & $\theta 0=0$ & & -000 \\
\hline myosin VIla & -3 & E- & & 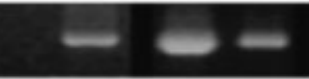 \\
\hline Brn 3.1 & -- & $-1-1$ & & $=-$ \\
\hline$\alpha 9$ AchR & -- & - & & $-\infty$ \\
\hline$\alpha 10$ AchR & & -- & & $-\quad-$ \\
\hline MATH-1 & - & & & 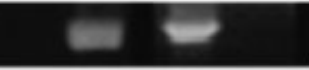 \\
\hline pendrin & 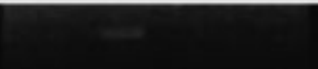 & - & & -2 \\
\hline jagged-2 & 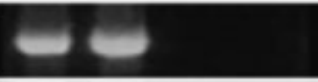 & טك- & & $00-$ \\
\hline Notch-1 & 0 & 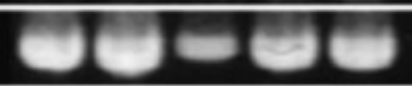 & & 60 \\
\hline HES-1 & -6 & Eu & & -0 \\
\hline HES-5 & - & & & -2 \\
\hline jagged-1 & $\theta$ & $0-\infty-\infty$ & & $-0-$ \\
\hline$\alpha$-tectorin & -- & - & & -0 \\
\hline$\beta$-tectorin & & & & - \\
\hline GADPH & 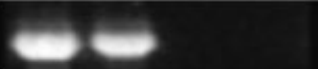 & ש & & -20 \\
\hline
\end{tabular}

Fig. 1. Reverse transcriptase-polymerase chain reaction (RT-PCR) for genes involved in bone morphogenetic protein (BMP) signaling and for markers of various phenotypes in the developing ear. RNA was harvested from uncloned, unsorted Immortomouse otocysts (UIMO) and from clonal cell line IMO-2B1, under proliferative conditions and after differentiation for 3, 7, 15, or 30 days. For all RT-PCR experiments, the same quantity of RNA was used in each lane and for all rows, to help permit rough comparison of signal intensity among different genes. Glutaraldehyde phosphate dehydrogenase (GAPDH) was amplified 25 cycles; all the other cDNAs were amplified 35 cycles. (-)RT, controls lacking reverse transcriptase; Inner Ear, control RNA harvested from inner ears of postnatal day 1 mouse inner ear; E, embryonic day. 

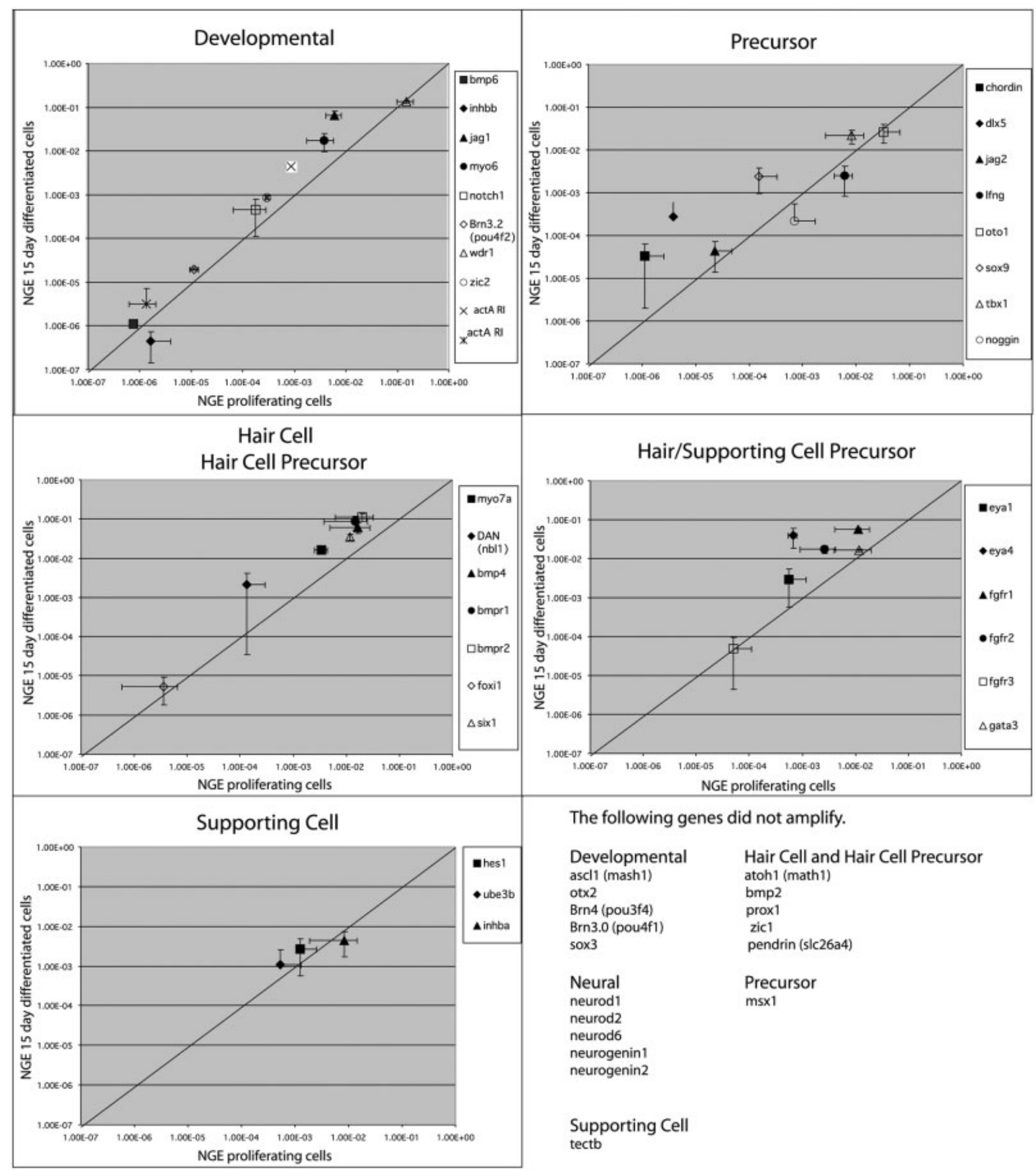

The following genes did not amplify.

$\begin{array}{ll}\begin{array}{l}\text { Developmental } \\ \text { ascl1 (mash1) }\end{array} & \begin{array}{l}\text { Hair Cell and Hair Cell Precursor } \\ \text { atoh1 (math1) } \\ \text { otx2 } \\ \text { bmp2 }\end{array} \\ \begin{array}{l}\text { Brn4 (pou3f4) } \\ \text { Brn3.0 (pou4f1) }\end{array} & \begin{array}{l}\text { zrox1 } \\ \text { pendrin (slc26a4) } \\ \text { sox3 }\end{array} \\ \begin{array}{l}\text { Neural } \\ \text { neurod1 }\end{array} & \begin{array}{l}\text { Precursor } \\ \text { neurod2 }\end{array} \\ \text { neurod6 } & \text { msx1 } \\ \text { neurogenin1 } & \\ \text { neurogenin2 } & \end{array}$

Supporting Cell

Fig. 2. Real-time quantitative polymerase chain reaction (rt-qPCR) analysis of proliferating (x-axis) and 15-day differentiated (y-axis) IMO-2BI cells. Gene expression is normalized to GAPDH and plotted on a logarithmic scale scatter graph. Genes neither up nor down regulated fall on the diagonal. Upregulated genes fall above the diagonal; downregulated genes fall below the diagonal. A list of genes that were not amplified is also included. NGE, normalized gene expression.

\section{Expression of Phenotypic Markers of Supporting Cells and Nonsensory Epithelia}

Expression of pendrin and many other markers of the SC phenotype were detected in both UIMO cells and proliferative clonal $\mid \mathrm{MO}-2 \mathrm{~B} 1$ (Fig. 1; Table 1). In IMO-2B1, expression of $\alpha$-tectorin and pendrin followed a bimodal temporal pattern similar to that of some of the $\mathrm{HC}$ genes described above, with expression dropping during the early phases of differentiation, then recovering by 30 days. In UIMO, $\alpha$-tectorin was easily detected at both stages, but pendrin only appeared 
in the differentiated cells. At least one cell line (IMO3C3) expresses enough pendrin to make it potentially useful for study of this gene, which is implicated in Pendred syndrome (Table 1). $\beta$-tectorin was not detected in either cell population by conventional PCR.

The cell lines were uniformly positive for HES-1, Notch-1, and jagged-1 at relatively high levels; Notch-1 was particularly abundant. $\alpha$-tectorin, a component of the tectorial membrane, was detected at moderate levels in all lines both before and after differentiation. In strong contrast is the finding that two other supporting cell markers, $\beta$-tectorin and HES-5, were not detectable in UIMO or IMO-2BI cells by conventional PCR. The finding of divergent gene expression profiles in IMO cell lines supports the idea that phenotypic gene regulation may indeed occur in IMO cells, i.e., they are not simply expressing all their genes indiscriminately.

\section{Expression of Zic Genes, Which May Be Involved in Cell Fate Decisions}

Expression of the zinc-finger-of-thecerebellum gene family members Zicl and Zic2 (Warner et al., 2003) were measured during the screening of the seven clonal IMO cell lines (Table 1). Many cell lines expressed one or both Zic genes. Zic2 was particularly abundant in IMO-2B1. Zic2 expression increased significantly with differentiation in three cell lines: $1 G 1,2 \mathrm{D} 2$, and 3D1. Whereas most cell lines expressed Zic2, very few expressed Zic 7. The notable exception is IMOIG1, which has significant levels of Zic 7 mRNA in both proliferative and differentiated cultures. We hypothesize that the Zic genes are part of a signaling cascade that is downstream of BMP4 and its molecular antagonist chordin (Elms et al., 2003) and that up-regulation of Zicl in a precursor cell common to both neurons and $\mathrm{HCs}$ in turn up-regulates the atonal gene neuroD 1, leading to a neuronal fate. In contrast, we hypothesize that up-regulation of Zic2 leads to up-regulation of a different atonal class gene, Math 1, resulting in a $\mathrm{HC}$ fate (Barald and Kelley,
2004). These cell lines provide an ideal system to test and model these molecular regulatory cascades.

\section{rt-qPCR}

Because of the relatively high cycle numbers (35), the qualitative PCR assay could only be used to determine whether a cell line expressed or did not express the cDNA. Only rt-qPCR results, using the methods of Stankovic and Corfas (2003), are quantitative. We compared these two methods on the IMO-2BI cell line (Table 1; Figs. 1, 2).

We performed rt-qPCR on both proliferating and 15-day differentiating IMO-2BI cells using 50 primer pairs (Fig. 2). As with the conventional PCR, we found that Math-1, Zicl, and $\beta$-tectorin were not expressed. We found that the following genes also were not expressed: Mash-1, BMP2, neurod1, neurod2 and neurod6, neurogenin 1 and 2, otx2, msx1, POU3F4 (Brn4) and POU4F1 (Brn3a), Proxl, and pendrin (slc26a4). Genes that were downregulated slightly include inhibin b $(4 x)$, noggin $(3 x)$, and lunatic fringe $(3 x)$. Several genes were slightly upregulated (Fig. 2). Genes up-regulated more than 10-fold included DAN (nbl1)(16x), chordin (20x), sox9 (15x), and jag 1 (11x). Dlx5, which appears to be a key player in early inner ear induction (Liu et al., 2003b), was up-regulated more than 72-fold, and Eya4 was up-regulated 60-fold (Fig. 2; Barald and Kelley, 2004). Primers for Brn3. 1, HES-5, and the $\alpha 9$ and $\alpha 10$ AChRs are still under development.

\section{Most of the Cell Lines Cloned to Date Express BMP4 and Notch/Delta Signaling Genes}

Early in our analysis, it became clear that most of the IMO cell lines we had cloned from the very early otocyst (embryonic day 9.5) expressed very high levels of BMP signaling genes under both proliferating and differentiated conditions (Table 1; Figs. 1, 3). To date, we have found only 6 clonal lines of the 27 initially screened that either do not express BMP4 or express it at very low levels. The characterization of these BMP- negative cell lines is in progress with rt-qPCR. BMP4 appears to be secreted in active form in considerable quantity, as we showed previously with the cell line IMO3C6 (Gerlach et al., 2000). Implantation of beads carrying cells that make the BMP4 antagonist noggin into the developing inner ear caused abnormal development of semicircular canals (Gerlach et al., 2000). However, coimplantation of the IMO3C6 cell line, which produces large amounts of BMP4, rescued the noggin-induced canal loss. Many IMO cells also express high levels of BMP receptors and BMP antagonists in addition to the growth factors themselves. These cells should provide ideal model systems for further study of this very complex signaling system, with its multiple interactions among similar growth factors, receptors, binding proteins, and feedback loops.

IMO cells also appear to express, simultaneously, very high levels of gene products involved in Notch signaling, including Notch-1 and its ligand jagged-2. This, combined with their ability to express genes associated with both $\mathrm{HC}$ and non-HC phenotypes, makes them potentially useful models for study of phenotype specification by means of this signaling paradigm.

\section{Expression of Genes Found in Mature HCs}

The gene expression profiling experiments highlight two interesting and consistent properties of these conditionally immortalized cells. First, despite their origins from the primitive otocyst, many cell lines express genes that, in vivo, are typically associated with more mature cell types, such as the myosins, tectorins, and AChRs. Moreover, they do so even when proliferating, i.e., under conditions permissive for expression of the immortalizing transgene. Clearly, it would be too simplistic to think of the proliferative IMO cells as being suspended in a primitive otocyst-like state under the culture conditions used here. However, it would be equally simplistic to posit the opposite, i.e., that proliferative cells have already fully differentiated, be- 
cause they continue to express high levels of "early" inner ear genes, such as BMP4. Second, as a general rule, we found little variation in expression levels for most genes when the cells were switched to differentiating (nonpermissive) conditions, although there were exceptions. In future applications in inner ear research, abundant gene expression in proliferating cells would be desirable, such as in dissection of factors regulating their transcription, because it is more convenient to work with stable proliferative cells. However, demonstration of changes in gene expression associated with commitment to certain cell fates, will likely require additional exogenous signals, because the cells do not demonstrate such shifts under our simple "default" culture conditions.

Our otocyst-derived cells are not unique among inner ear cell lines in their propensity to express mature phenotypes before being induced to differentiate. Conditionally immortalized organ of Corti cells UB/ OC-2 express many hair cell markers under proliferative conditions, including myosin VIla, $\alpha 9$ AChR, and Brn3.1, and continue to do so after differentiation (Rivolta et al., 1998), whereas another cell line, UB/OC-1, by contrast, up-regulates the same genes. Similarly, another HC maker, myosin $\mathrm{Vl}$, is strongly expressed by both cell lines in proliferative conditions and is unchanged after differentiation (Rivolta et al., 1998). Although these findings parallel our own results regarding expression of some HC genes, they may also reflect the later stage at which the cells were derived (E13). Also interesting are findings from another Immortomouse cell line, UB/UE-1, derived from P2 utricle (Lawlor et al., 1999). These postnatal supporting cells were shown to acquire characteristics of HCs after differentiation. However, expression of several HCspecific genes was also found before differentiation, including Brn3.1 and myosin6, although others were undetected (myosin VIla, $\alpha 9 A C h R$ ). These results and our own remind us that it should not be assumed that the gene expression profile of immortalized inner ear cells is identical to that of their cells of origin.
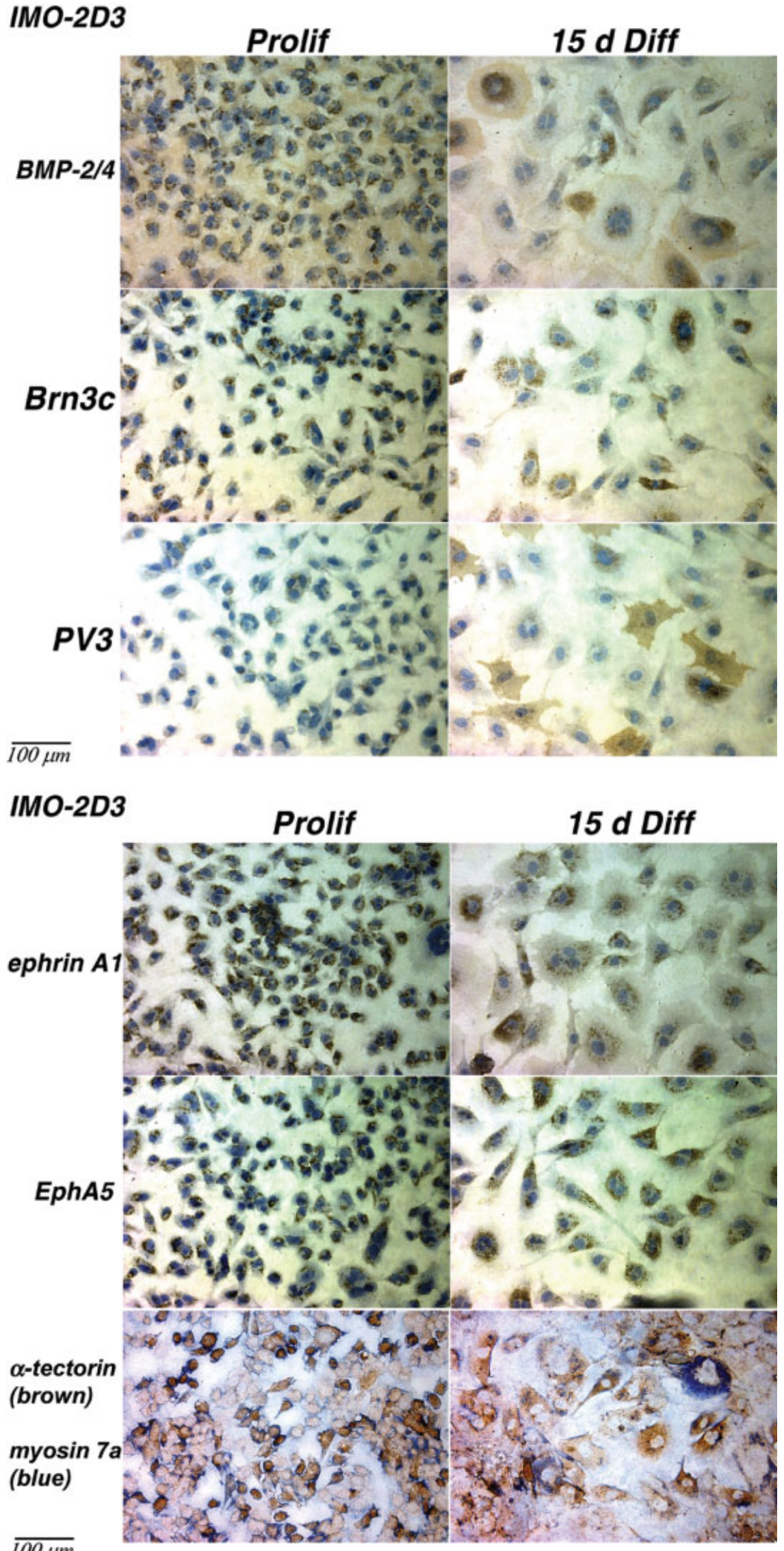

Fig. 3. 


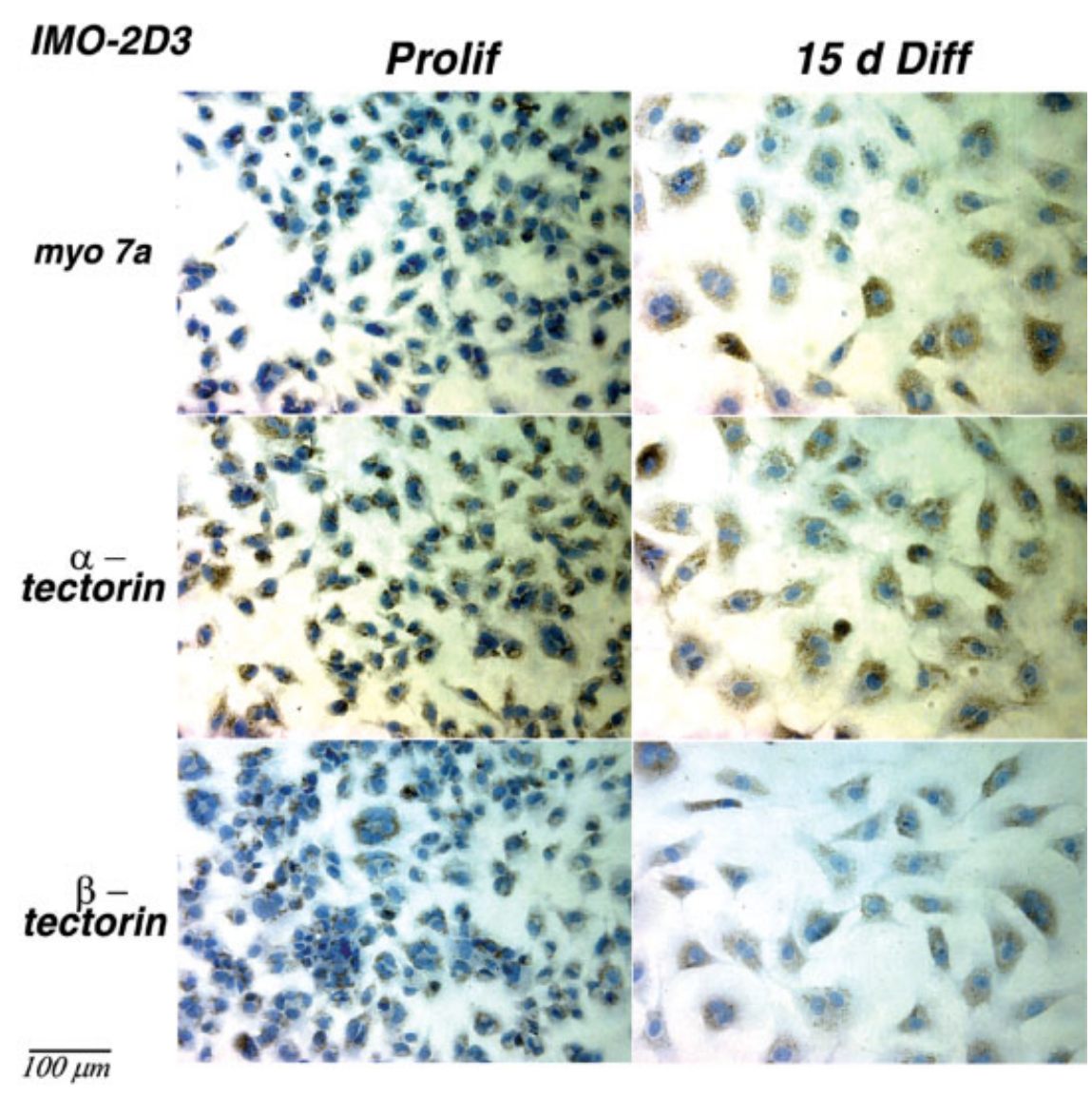

Fig. 3. Single-label and one double-label immunocytochemical localization of various antigens in a representative clonal cell line, IMO2D3. Cells are shown under proliferative conditions (Prolif, $32^{\circ} \mathrm{C},+\gamma$ interferon) and after 15 days in differentiation conditions ( $15 \mathrm{D} \mathrm{Diff}, 37^{\circ} \mathrm{C}$, - interferon). A-C: Antibodies in the single-label experiments (all but the two bottom panels in Fig. 3C) were localized with peroxidase-diaminobenzidine (DAB; brown labeling) and nuclei were counterstained with hematoxylin. This cell line labeled positively for each antibody tested except the control secondary antibody used alone (rabbit immunoglobulins; data not shown). Labeling was relatively uniform in the smaller, proliferative cells, but for several proteins, considerable intercellular variability in labeling intensity was observed after differentiation (bone morphogenetic protein (BMP)2/4, and hair cell (HC) markers Brn3c, parvalbumin 3 (PV3), and myosin Vlla, and supporting cell (SC) marker ephrin Al). Other genes (tectorins) had somewhat more uniform labeling among all cells in each group. Bottom two panels in C: Double-label immunocytochemistry for a SC marker. $\alpha$-tectorin (brown labeling, peroxidase-DAB), followed by antibody to a $\mathrm{HC}$ marker, myosin Vlla (blue labeling, alkaline phosphatase-Vector blue substrate). No counterstaining was performed. Variable labeling was seen for both antibodies, particularly myosin Vlla, which appeared to label fewer cells than did $\alpha$-tectorin. Cells positive for myosin Vlla (blue) also generally were positively labeled for $\alpha$-tectorin, suggesting that the cells do not develop separate distinct HC and SC phenotypes. Many other cells showed little or no labeling for either antibody, suggesting the existence of a possible nonsensory phenotype. IMO, conditionally immortalized otocyst; PV3, parvalbumin.

\section{Immunocytochemistry Shows Cell Heterogeneity}

Immunocytochemistry was used to investigate patterns of protein expression at the cellular level, on monolayer cultures of UIMO cells and several clonal cell lines under proliferative conditions and after 15 days of differentiation (Fig. 3). This investigation was done both to confirm expression as seen in reverse finding that mRNAs for both the $\mathrm{HC}$ and SC phenotype were simultaneously detected in RNA from many IMO cell populations (Fig. 3C).

\section{Multiple Phenotypes in One Cell}

It was of considerable interest that individual IMO cells express characteristics of multiple phenotypes (Fig. 3C). This finding suggests that these earlyotocyst-derived cell populations retain at least some potential for acquiring multiple inner ear phenotypes, which may be characteristic of an early precursor or common progenitor cell. These phenotypes are what would be expected of otocyst progeny, that is, both sensory and nonsensory epithelial cells. The otocyst is also the origin of the acoustic/spiral ganglion and auditory nerve, and so might also be expected to have proneuronal potential. We have tested this aspect of the cells' capabilities in preliminary experiments in this study. A notable finding from the PCR experiments was that most IMO cells express genes for different phenotypes simultaneously. We hypothesized that this finding could result from differential phenotype development in different cells within single cultures and, thus, designed the immunocytochemical experiments to test this hypothesis. $\mathrm{HCs}$ and SCs in vivo are known to originate from a common precursor (Fekete et al., 1998). The alternate hypothesis was that gene expression would be uniform from cell to cell within each cell line.

The cosegregation of $\mathrm{HC}$ and SC markers to certain cells, while at the same time their neighbors lack either, might signify the existence of a prosensory phenotype that activates both genes but is incapable of further differentiation into $\mathrm{HC}$ or $\mathrm{SC}$ in the absence of other signals in vitro. Determining the identity of those neighbors lacking either $\mathrm{HC}$ or SC gene expression will have to await future study, but one could postulate that they represent other otocyst derivatives, such as nonsensory epithelial cells, neuronal/proneuronal cells, or more primitive undifferentiated cells.

Differential phenotypic development within clonal inner ear cell lines 
has been demonstrated by others at later stages of immortalization. In postnatal utricle cell line UB/UE-1, clear segregation among neighboring cells is seen in their loss of cell labeling for cytokeratin upon differentiation, signifying the onset of distinct HC-like cells (Rivolta and Holley, 2002a). Moreover, only $50 \%$ of cells acquired slow-acting rectifier currents similar to HCs, with only a subset developing the fast inward rectifier currents, and finally only approximately 3\% develop actin ring structures, all suggesting the variable expression of $\mathrm{HC}$ phenotype and/or the presence of multiple phenotypes.

Kalinec et al. (1999) report differential expression of nestin in P14 Immortomouse organ of Corti cell lines after 1 week of differentiation, with considerable differences appearing even between neighboring cells. Both UB/UE-1 and the Kalinec OC cells also appear to demonstrate asymmetric cell divisions at the time of differentiation (Rivolta and Holley, 2002b; Kalinec et al., 1999), which may be one mechanism by which clonal cells develop divergent phenotypes. By contrast, the well-studied organ of Corti cell lines UB/OC-1 and UB/OC-2 demonstrate uniform phenotypes when studied by immunocytochemistry (Rivolta et al., 1998).

The effects of the immortalizing oncogene that were discussed in great detail by the laboratory that originated the transgenic mouse from which these and many other kinds of cell lines were derived (Noble, 1999) apply to these cells as well as to cell lines from other organs that were derived from these animals. However, a study of the regenerative capacity of these cells in the presence of an immortalizing oncogene has not yet been done in this or any other system.

\section{CONCLUSIONS \\ Otic Cell Lines Provide a Good Model System for Inner Ear Development}

Our results indicate that IMO cell lines can express a broad repertoire of genes found in both the develop- ing and mature inner ear, including important signaling genes and markers of various inner ear phenotypes. The results of these studies suggest that IMO cell lines are capable of developing characteristics of multiple cell types of the mature inner ear in culture, but the relationships between phenotype development and differentiation status of the IMO cells are not simple.

Many researchers who want to use these cell lines ask how closely they approximate the phenotypically differentiated $\mathrm{HC}$ or SC. The answer is that they do not bear a phenotypic resemblance to these cells. We never see stereocilia on these cells unless we transfect them with specific cytoskeletal elements (Cleveland et al., manuscript in preparation); nor do they express differentiated SC markers. However, we believe that they serve as an excellent model system to study early cues and influences on multipotent precursor or progenitor cells that can direct these cells into different differentiated cell pathways.

IMO cells are easy to maintain in large volumes, and their gene expression patterns remain reproducible over many experiments/passages. Moreover, they express many inner-ear-specific genes at high levels and do not require prolonged differentiation periods to do so. These cells are useful for predictive molecular studies, for example, analysis of inner-ear-specific regulation of their gene promoter regions (Thompson et al., 2003). Although all of the individual cell lines characterized here express BMP4, they present different gene expression profiles for other markers. For example, the 3D1 cell line expresses neither chordin nor noggin at any stage, while the IMOIG1 cell line expresses both BMP4 inhibitors, and noggin increases upon differentiation (Table 1). IMOIG1 is also the only cell line that increases its expression of $\mathrm{Zicl}$ to high levels on differentiation (Table 1). IMO-2B1 cells increase expression of Zic2 on differentiation, as shown by conventional PCR (Table 1) and by rt-qPCR (Fig. 2).

These IMO cell lines provide a reliable, renewable, manipulable model system in which to study gene regula- tion in the early auditory system. We have used this system to good effect to discover a novel intron 2 promoter in the BMP4 gene expressed in the inner ear, which is down-regulated by all-trans retinoic acid (Thompson et al., 2003). Initial molecular studies in the IMO-2BI cell line were then verified in "real" inner ears of chicks and mice. These findings can now explain why the results of exogenous RA application to the early developing inner ear (Choo et al., 1998) and BMP4 antagonist application (Chang et al., 1999; Gerlach et al., 2000) result in the same phenotypic abnormalities and solve a long-standing controversy in the literature.

We hypothesized that certain cell lines might recapitulate the differentiation of mature auditory cells from their primitive precursors. We determined the phenotypic potential of some of these isolated cell lines, both in a global sense, as synchronized whole cultures, and in a local sense, as individual cells acting under influence of their neighbors. We found that a given cell line can express markers of multiple differentiated auditory cell types (Fig. 3C). Individual cells within the clone vary in expression of these markers. We believe that these cell lines represent at least multipotential precursor populations capable of responding to localized molecular signals from their neighbors and the environment. The null hypotheses, which these data do not support, is that IMO cells either maintain a primitive phenotype in culture or proceed to differentiate in a uniform manner into a single mature fate. The latter, in particular, is important to test in clonal cell lines, because each line represents the progeny of a single cell from the original otocyst. If the ultimate fate of otic cells were already determined by the otocyst stage, then each clonal cell line might be expected to proceed uniformly to a single phenotype. This process was clearly not the case in UIMO cells. Several clonal lines expressed characteristics of multiple cell types of the developing inner ear.

One obvious question is how the culture conditions elicit responses from the cells. Another issue is the influence that neighboring cells 
have on the differentiation patterns of specific cells in the culture. Considerations include how many cellcell contacts a given cell encounters as it differentiates (colony effects), the sequence of a specific cell's differentiated gene expression, as well as limitations on differentiation presented by diminishing concentrations of certain factors, including serum factors and cell-derived growth factors and $\gamma$-interferon, but also cell-secreted factors that we have yet to identify.

\section{EXPERIMENTAL PROCEDURES Otocyst Cell Lines}

Conditionally immortalized cells derived from the otocyst of 9.5-day embryos of the $\mathrm{H} 2 \mathrm{k}^{\mathrm{b}}$ tsA58 Immortomouse were maintained as either proliferative or differentiated cells as previously described (Barald et al., 1997; Thompson et al., 2003). Uncloned, unsorted Immortomouse otocyst (UIMO) cells, representing a random sample of the entire otocyst, and clonal cell lines (e.g., IMO2B1, IMO2D3, and IMO1G1; Table 1) derived from this uncloned population were analyzed. Chinese hamster ovary cells were used as negative controls for immunocytochemistry experiments and were grown under the proliferative and differentiation conditions defined for IMO cells. These cells do not express BMP4 (Gerlach et al., 2000).

\section{RNA Preparation, Reverse Transcription, and PCR}

RNA preparation, reverse transcription, PCR, and rt-qPCR were performed with appropriate controls and cycle conditions as previously described (Thompson et al., 2003) by using primers designed for either conventional PCR or quantitative PCR. We designed the primer pairs for rt-qPCR study to unique areas of each gene using the Beacon Designer program (Bio-Rad) using a target $\mathrm{Ta}$ of $55^{\circ} \mathrm{C}$, length $18-22$, and amplicon size 70-200. The primers were synthesized from our designed sequences by InVitrogen Life Technologies (Carlsbad, CA). For the quantitative study, we used
SYBRgreen-based detection on a Bio-Rad iCycler. All of these primer sequences are available by email request (kfbarald@umich.edu).

\section{Normalized Gene Expression for rt-qPCR}

The efficiency $(E)$ of each primer set was determined using dilutions of day-12 mouse embryo cDNA. Each primer set was then used to amplify IMO-2B1 CDNA made from proliferating cells or from 15-day differentiated cells and the critical threshold (Ct) was determined. The gene expression was normalized to the housekeeping gene glutaraldehyde phosphate dehydrogenase (GAPDH) using the formula described by Stankovic and Corfas (2003):

$$
N G E=\frac{\left(E_{\text {target }}\right)^{\overline{-C_{\text {target }}}}}{\left(E_{\text {GAPDH }}\right)^{\overline{-C t_{\text {GAPDH }}}}} .
$$

The normalized gene expression was plotted on a logarithmic scale scatter graph on which it is easy to depict both up- and down-regulation and the relative abundance of the genes compared with GAPDH. Genes neither up- nor down-regulated fall on the diagonal. Up-regulated genes fall above the diagonal; down-regulated genes fall below the diagonal. A list of genes that were not amplified is also included (Fig. 2).

\section{Cell Preparation for Immunocytochemistry}

IMO cells were plated on eight-well glass slides (Nunc LabTekll), and allowed to proliferate under permissive conditions until they were approximately $70-80 \%$ confluent, at which point some cultures were fixed for immunocytochemical analysis of the proliferative phenotype, and others were switched to differentiation conditions for an additional 15 days (as in Barald et al., 1997). Fixation, permeabilization, binding and blocking conditions, and single and double labeling were performed as previously described (Gardner and Barald, 1991).

\section{Antibodies}

Affinity-purified rabbit anti-human myosin VIla, specific for a portion of the tail (AA 880-1070), provided by Tama Hasson through an MTA from University of California at San Diego, was used at $10 \mu \mathrm{g} / \mathrm{ml}$; rabbit antiserum to PV3, the kind gift of Stefan Heller, Harvard University, was used at 1:2,000; rabbit polyclonal antiserum to Brn 3.1/Brn3c (BabCo-Covance PRB-249C) at 1:500; rabbit antisera to the tectorins (R9 anti- $\alpha$ tectorin, R7 anti- $\beta$-tectorin) were the kind gift of Guy Richardson, University of Sussex; each was used at 1:200; rabbit anti-phrin A1 and rabbit anti-EphA5 were from Santa Cruz, both were used at 1:100; rabbit isotype control (Zymed, 08-6199) and mouse isotype control (Zymed, 086599) were both used undiluted; monoclonal mouse anti-BMP2/4 (H3B2/17.8.1) were obtained from Genetics Institute (Gl) through an MTA and were used at $10 \mu \mathrm{g} / \mathrm{ml}$. Under our MTA agreement with Gl, Wyeth (who absorbed Gl) was allowed to examine this manuscript for 30 days before its submission. Monoclonal anti-pan cytokeratin (Sigma C2562) was used at 1:100 (157 $\mu \mathrm{g} /$ $\mathrm{ml}$; as in Rivolta et al., 2002).

\section{ACKNOWLEDGMENTS}

We thank Drs. Margaret Lomax, University of Michigan, and Matthew Kelley, NIH, for helpful discussions and comments on the manuscript. Thanks to Dr. David Molea for help with Adobe Photoshop. K.F.B. was funded by the NIH and NSF; J.A.G. and K.F.B. were funded by the Deafness Research Foundation, and J.A.G. received a Resident Research Award from the American Academy of Otolaryngology-HNS. J.S.H. was supported by an NSF REU supplement to K.F.B.

\section{REFERENCES}

Adam J, Myat A, Le Roux I, Eddison M, Henrique D, Ish-Horowicz D, Lewis J. 1998. Cell fate choices and the expression of Notch, Delta and Serrate homologues in the chick inner ear: parallels with Drosophila sense-organ development. Development 125:4645-4654.

Barald KF, Kelley MW. 2004. From placode to polarization: new tunes in inner ear development. Development 131:41194130.

Barald KF, Lindberg $\mathrm{KH}$, Hardiman $\mathrm{K}$, Kavka Al, Lewis JE, Victor JC, Gardner CA, Poniatowski A. 1997. Immortalized 
cell lines from embryonic avian and murine otocysts: tools for molecular studies of the developing inner ear. Int J Dev Neurosci 15:523-540.

Bermingham NA, Hassan BA, Price SD, Vollrath MA, Ben-Arie N, Eatock RA, Bellen HJ, Lysakowski A, Zoghbi HY. 1999. Math1: an essential gene for the generation of inner ear hair cells. Science 284:1837-1841.

Brigande JV, Kiernan $A E$, Gao X, Iten LE, Fekete DM. 2000a. Molecular genetics of pattern formation in the inner ear: do compartment boundaries play a role? Proc Natl Acad Sci U S A 97:11700-11706.

Brigande JV, Iten LE, Fekete DM. 2000b. A fate map of chick otic cup closure reveals lineage boundaries in the dorsal otocyst. Dev Biol 227:256-270.

Chang W, Nunes FD, De Jesus-Escobar JM, Harland R, Wu DK. 1999. Ectopic noggin blocks sensory and nonsensory organ morphogenesis in the chicken inner ear. Dev Biol 216:369-381.

Choo D, Sanne JL, Wu DK. 1998. The differential sensitivities of inner ear structures to retinoic acid during development. Dev Biol 204:136-150.

Cole LK, Le Roux I, Nunes F, Laufer E, Lewis J, Wu DK. 2000. Sensory organ generation in the chicken inner ear: contributions of bone morphogenetic protein 4 , serratel, and lunatic fringe. J Comp Neurol 424:509-520.

Echteler SM, Fay RR, Popper AN. 1994. Structure of the mammalian cochlea. In: Fay RR, Popper AN, editors. Comparative hearing: mammals. Springer handbook of auditory research. Vol. 4. New York: Springer. p 134-171.

Elgoyhen AB, Johnson DS, Boulter J, Vetter DE, Heinemann S. 1994. Alpha9: an acetylcholine receptor with novel pharmacological properties expressed in rat cochlear hair cells. Cell 79:705-715.

Elgoyhen $A B$, Vetter DE, Katz E, Rothlin CV Heinemann SF, Boulter J. 2001. Alpha 10: a determinant of nicotinic cholinergic receptor function in mammalian vestibular and cochlear mechanosensory hair cells. Proc Natl Acad Sci U S A 98:3501-3506.

Elms P, Siggers P, Napper D, Greenfield A, Arkell R. 2003. Zic2 is required for neural crest formation and hindbrain patterning during mouse development. Dev Biol 264:391-406.

Erkman L, McEvilly RJ, Luo L, Ryan AK, Hooshmand $\mathrm{F}, \mathrm{O}^{\prime} \mathrm{C}$. Rapaport DH, Ryan AF, Rosenfeld MG. 1996. Role of transcription factors Brn-3 1 and Brn-3 2 in auditory and visual system development. Nature 381:603-606.

Fekete DM. 1996. Cell fate specification in the inner ear. Curr Opin Neurobiol 6:533-541.

Fekete DM. 2000a. Making sense of making hair cells. Trends Neurosci 23:386.

Fekete DM. 2000b. Ear rings: FGF3 involvement comes full circle. Trends Neurosci 23:332.

Fekete DM, Wu DK. 2002. Revisiting cell fate specification in the inner ear. Curr Opin Neurobiol 12:35-42.
Fekete DM, Muthukumar S, Karagogeos D. 1998. Hair cells and supporting cells share a common progenitor in the chicken inner ear. J Neurosci 18:78117821.

Fritzsch B, Beisel KW. 2001. Evolution and development of the vertebrate ear. Brain Res Bull 55:711-721.

Fritzsch B, Silos-Santiago I, Bianchi LM, Farinas I. 1997. The role of neurotrophic factors in regulating the development of inner ear innervation. Trends Neurosci 20:159-164.

Gardner CA, Barald KF. 1991. The cellula environment controls the expression of engrailed-like protein in the cranial neuroepithelium of quail/chick-chimeric embryos. Development 113:1037-1048.

Gerlach LM, Hutson MR, Germiller JA, Nguyen-Luu D, Victor JC, Barald KF. 2000. Addition of the BMP4 antagonist noggin, disrupts avian inner ear development. Development 127:45-54.

Gerlach-Bank LM, Ellis AD, Noonen B, Barald KF. 2002. Cloning and expression analysis of the chick DAN gene, an antagonist of the BMP family of growth factors. Dev Dyn 224:109-115.

Glowatski E, Wild K, Brandle U, Fakler G Fakler B, Zenner HP, Ruppersberg JP. 1995. Cell-specific expression of the atpha9-n-Ach receptor subunit in auditory hair cells revealed by single-cel RT-PCR. Proc R Soc Lond B 262:141-147.

Hamburger V, Hamilton VL. 1951. A series of normal stages in the development of the chick embryo. J Morphol 88:49-92.

Hasson T, Gillespie PG, Garcia JA, MacDonald RB, Zhao Y, Yee AG, Mooseke MS, Corey DP. 1997. Unconventiona myosins in inner ear sensory epithelia. $\mathrm{J}$ Cell Biol 137:1287-1307.

Heller S, Bell AM, Denis CS, Choe Y, Hudspeth AJ. 2002. Parvalbumin 3 is an abundant $\mathrm{Ca} 2+$ buffer in hair cells. $J$ Assoc Res Otolaryngol 3:488-498.

Hemmati-Brivanlou A, Thomsen GH. 1995. Ventral mesodermal patterning in $\mathrm{Xe}$ nopus embryos: expression patterns and activities of BMP2 and BMP4. Dev Genet 17:78-89.

Hemond SG, Morest DK. 1991. Ganglion formation from the otic placode and the otic crest in the chick embryo: mitosis, migration, and the basal lamina. Anat Embryol (Berl) 184:113.

Hogan BL, Blessing M, Winnier GE, Suzuk N, Jones CM. 1994. Growth factors in development: the role of TGF-beta related polypeptide signaling molecules in embryogenesis. Dev Suppl :53-60.

Holley MC, Nishida Y, Grix N. 1997. Conditional immortalization of hair cells from the inner ear. Int J Dev Neurosci 15:541-552

Jat SJ, Noble MD, Ataliotis PM, Tanaka Y, Yannoutsos N, Larsen L, Kioussis D. 1991. Direct derivation of conditionally immortal cell lines from an $\mathrm{H}_{2} \mathrm{~K}^{\mathrm{b}}+\mathrm{s} \mathrm{A} 58$ transgenic mouse. Proc Natl Acad Sci U S A 88:5096-5100.

Kalinec F, Kalinec $G$, Boukhvalova M, Kachar B. 1999. Establishment and characterization of conditionally immortal- ized organ of Corti cell lines. Cell Biol Int 23:175-184.

Kawamoto K, Ishimoto S, Minoda R, Brough DE, Raphael Y. 2003. Math1 gene transfer generates new cochlear hair cells in mature guinea pigs in vivo. J Neurosci 23:4395-4400.

Kimble J, Simpson P. 1997. The LIN12/Notch signaling pathway and its regulation. Ann Rev Cell Dev Biol 13:333-361.

Kopan R, Cagan R. 1997. Notch on the cutting edge. Trends Genet 13:465-467. Lanford PJ, Lan $Y$, Jiang $R$, Lindsell $C$, Weinmaster $G$, Gridley T, Kelley MW. 1999. Notch signaling pathway mediates hair cell development in mammalian cochlea. Nat Genet 21:289-292.

Lang H, Fekete DM. 2001. Lineage analysis in the chicken inner ear shows differences in clonal dispersion for epithelial, neuronal, and mesenchymal cells. Dev Biol 234:120-137.

Lawlor P, Marcotti W, Rivolta MN, Kros CJ, Holley MC. 1999. Differentiation of mammalian vestibular hair cells from conditionally immortal, postnatal supporting cells. J Neurosci 19:9445-9458.

Legan PK, Rau A, Keen JN, Richardson GP. 1997. The mouse tectorins. Modular matrix proteins of the inner ear homologous to components of the spermegg adhesion system. J Biol Chem 272: 8791-8801.

Lewis J. 1996. Neurogenic genes and vertebrate neurogenesis. Curr Opin Neurobiol 6:3-10.

Liu W, Oh SH, Kang YkY, Li G, Doan TM, Little M, Li L, Ahn K, Crenshaw EB III, Frenz DA. 2003a. Bone morphogenetic protein 4 (BMP4): a regulator of capsule chondrogenesis in the developing mouse inner ear. Dev Dyn 226:427-438.

Liu D, Chu H, Maves L, Yan Y-L, Morcos PA, Postlethwait JH, Westerfield $M$. 2003b. Fgf3 and Fgf8 dependent and independent transcription factors are required for otic placode specification. Development 130:2213-2224.

Morsli H, Choo D, Ryan A, Johnson R, Wu DK. 1998. Development of the mouse inner ear and origin of its sensory organs. J Neurosci 18:3327-3335.

Noble M. 1999. Production and growth of conditionally immortal cell lines from the $\mathrm{H}$-2KbtsA58 transgenic mouse. Methods Mol Biol 97:139-158.

Oh SH, Johnson R, Wu DK. 1996. Differential expression of bone morphogenetic proteins in the developing vestibular and auditory sensory organs. J Neurosci 16:6463-6475.

Rivolta MN, Holley MC. 2002a. Cell lines in inner ear research. J Neurobiol 53:306318.

Rivolta MN, Holley MC. 2002b. Asymmetric segregation of mitochondria and mortalin correlates with the multi-lineage potential of inner ear sensory cell progenitors in vitro. Brain Res Dev Brain Res 133:49-56.

Rivolta MN, Grix N, Lawlor P, Ashmore JF, Jagger DJ, Holley MC. 1998. Auditory hair cell precursors immortalized from 
the mammalian inner ear. Proc R Sco Lond B Biol Sci 265:1595-1603.

Rivolta MN, Halsall A, Johnson CM, Tones MA, Holley MC. 2002. Transcript profiling of functionally related groups of genes during conditional differentiation of a mammalian cochlear hair cell line. Genome Res 12:1091-1099.

Ryan AF. 1997. Transcription factors and the control of inner ear development. Semin Cell Dev Biol 8:249-256.

Stankovic KM, Corfas G. 2003. Real-time quantitative RT-PCR for low-abundance transcripts in the inner ear: analysis of neurotrophic factor expression. Hearing Res 185:97-108.

Stone JS, Rubel EW. 2000a. Cellular studies of audatory hair cell regeneration in birds. Proc Nat Acad Sci USA 97:1171411721.
Stone JS, Rubel EW. 2000b. Temporal, spatial, and morphologic features of hair cell regeneratoin in the avian basilar papilla. J Comp Neurol 417:1-16.

Thomsen GH. 1997. Antagonism within and around the organizer: BMP inhibitors in vertebrate body patterning Trends Genet 13:209-211.

Thompson D, Gerlach-Bank LM, Barald KF, Koenig RJ. 2003. Retinoic acid repression of BMP4 in inner ear development. Mol Cell Biol 23:2277-2286.

Vahava $O$, Morell $R$, Lynch ED, Weiss $S$, Kagan ME, Ahituv N, Morrow JE, Lee MK, Skvorak AB, Morton CC, Blumenfeld $A$, Frydman $M$, Friedman TB, King MC, Avraham KB. 1998. Mutation in transcription factor POU4F3 associated with inherited progressive hearing loss in humans. Science 279:1950-1954.
Wall NA, Hogan BL. 1994. TGF-beta related genes in development. Curr Opin Genet Dev 4:517-522.

Warner SJ, Hutson MR, Oh SH, GerlachBank LM, Lomax MI, Barald KF. 2003. Expression of $\mathrm{ZIC}$ genes in the development of the chick inner ear and nervous system. Dev Dyn 226:702712

Weir J, Rivolta M, Holley MC. 2000. Notch signaling and the emergence of auditory hair cells. Arch Otol Head Neck Surg 126:1244-1248.

Xiang M, Gan L, Li D, Chen ZY, Zhou L, O'Malley BWJ, Klein W, Nathans J. 1997. Essential role of POU-domain factor Brn-3c in auditory and vestibular hair cell development. Proc Natl Acad Sci U S A 94:9445-9450. 